\title{
アルミナ超微粉の加圧鋳込み成形
}

田島 俊造, 鈴木 裕之, 黒木 英憲

広島大学工学部第一類, 干724 東厇島市鏡山1-4-1。

\section{Pressure Slip Casting of Submicron Alumina Powder}

Shunzo Tashima, Hiroyuki Suzuki and Hidenori Kuroki

Clusterl, Fac. Eng., Hiroshima University, 1-4-1 kagamiyama, Higashi-Hiroshima 724.

Compacts are formed by pressure (0.9MPa) slip casting from a submicron $\mathrm{Al}_{2} \mathrm{O}_{3}$ powder using sheet filter. The process is compared with the conventional one using plaster mold. Two types of filters are ; 1. acetyl-cellulose sheet with the thickness of $125 \mu \mathrm{m}$ and the hole size of $0.2 \mu \mathrm{m}$ backed by a plate of porous aluminum ; 2 . plaster mold reinforced by analuminum tube. An $\mathrm{Al}_{2} \mathrm{O}_{3}$ powder with the average particle size of $0.22 \mu \mathrm{m}$ and the purity of $99.99 \%$ is dispersed in a ball mill to prepare slips with coefficients of viscosity in the range of $400 \sim$ $600 \mathrm{mPa} \cdot \mathrm{sec}$.

The results obtained are sumarized as followes:

1. The rate of increase in the depth of the cake formed from the slip is represented by a constant $K=L^{2} / t$ ( $L$ :the thickness of the cake [m] , $t$ :the time [min]). The value of $K$ is $0.08 \mathrm{~mm}^{2} / \mathrm{min}$ in conventional slip casting with the plaster mold and about $1.0 \mathrm{~mm}^{2} / \mathrm{min}^{2}$ in pressure slip casting with the plaster mold or the cellulose sheet.

2. The sintering of the compacts are obstracted by the contamination from a plaster mold. The thickness of the contaminated layer in the compacts is about a few millimeter from the cake-mold interface.

3. Density of 99 to $99.5 \%$ and bending strength above $700 \mathrm{MPa}$ are obtained in the alumina compacts sintered at $1250^{\circ} \mathrm{C}$ for $1.5 \mathrm{hr}$, in the pressure slip casting with the acetyl-cellulose sheet filter.

1 緒 論

最近, ファインセラミックスを強勒な機械部品として 用いるためサブミクロン粉末を均一かつ高密度に固化す
る成形技術の開発か強く望まれている1-3) 。その一つと して泥漿による鋳込み成形法が注目され，泥貲を滤過， 着肉させる方法として，従来の石高型に代えて多孔樹脂 
型を使用し加圧成形する方法が報告されている2-4) .こ の方法では成形体の污染が少なく加圧により成形速度も 改善されるなどの特長を有するが，なお目詰まりが発生 し易く型の寿命が不安定，型材中の気孔径の制御が困難 などの問題がある.

本実験では，泥墏を濾過する材料としてセルロース・ シートを使用する加圧鋳込み成形を試み，正確な着肉速 度の測定方法を確立して着肉速度定数を求めると共に， 成形体の諸特性などを評価して実用化の可能性を検討し た.さらに、従来の石骨型を使用した鋳込み成形法との 比較も行った.

\section{2 実験方法}

\section{1 使用材料}

本実験で使用した市販アルミナ粉末（大明化学製タイ ミクロンTM-DAR) の特性をTable 1に示す. 2 次凝集粒子 の少ない単粒子に粉研されたもので，非常に微細かつ高 純度である. 分散処理の条件及び泥漿の特性は Table 2 に示すように既報らとほとんと同様である.すなわち， 分散剂にはポリカルボン酸アンモニウム（東亚合成化学 製アロンA-6114）を，結合剂にはアクリルポリマー（東 亜合成化学製AS-7503)を用い，結合剂の添加量は成形体 強度を検討して0.1mass％とした。泥墏の粘度はずり速 度19. $2 \mathrm{~s}^{-1}$ において400〜 600mPa·sであった。

なお，泥禁の水分量は22～28\%で検討したところ，低 い場合に多少着肉速度が速いほかは，成形体，焼成体の いずれに対しても影響が小さかったので，25\%の場合に

Table 1 Properties of the alumina powder used.

\begin{tabular}{|l|c|c|c|c|c|c|c|}
\hline Purity & $99.99 \%$ & \multicolumn{4}{|c|}{ Impurity (ppm) } \\
\hline Surface area & $15.1 \mathrm{~m}^{2} / \mathrm{g}$ & $\mathrm{Si}$ & $\mathrm{Fe}$ & $\mathrm{Na}$ & $\mathrm{K}$ & $\mathrm{Ca}$ & $\mathrm{Mg}$ \\
\hline Average particle size & $0.22 \mu \mathrm{m}$ & 13 & 9 & 3 & 2 & 2 & 1 \\
\hline
\end{tabular}

(Analytical values by Taimei-Chemical Company)

Table 2 Compositions and properties of slips.

\begin{tabular}{|l|l|}
\hline $\begin{array}{l}\text { Solvent } \\
\text { (Ion-exchanged water) }\end{array}$ & 25 mass\% \\
\hline $\begin{array}{l}\text { Dispersion agent } \\
\text { (Poly-carboxylic ammoni um) }\end{array}$ & 0.6 mass\% \\
\hline $\begin{array}{l}\text { Binder } \\
\text { (Acrylic polymer) }\end{array}$ & 0.1 mass\% \\
\hline Dispersion time & $16 \sim 48 \mathrm{hr}$ \\
\hline Coefficient of viscosity & $\begin{array}{c}400 \sim \\
600 \mathrm{mPa} \cdot \mathrm{s}\end{array}$ \\
\hline
\end{tabular}

\section{ついてのみ示す .}

\section{2 成形法}

成形法の概略をFig.1に示す。内径 $10 \times$ 高さ $90 \mathrm{~mm}$ (肉厚 $3 \mathrm{~mm})$ のアルミニウム製の金型底部を所定の多孔体で塞い で泥禁を装填，上部より0.9MPaの圧縮空気を送って成形 した.

底部は，1．シート状フィルター(酢酸セルロース製， 厚さ $125 \mu \mathrm{m}$ ，孔径 $0.2 \mu \mathrm{m}$ ）の背後に多孔金型を置いたも の；2. 石衰型を金枠で補強したもの；の2種類とし た.なお,石亳型では加圧しない通常の鋳込みも行った。 2.3 着肉厚さ測定

従来，泥嶈鋳込み成形法の着肉厚さ測定は，所定時間 着肉後に泥奬を排出し，型に付着した部分を着肉層とし て扱う方法"が一般的である.しかし，この方法では着 肉層上部に流動性の低下した泥漿が中間層として付着残 留しているので，その部分は乾燥焼成時の収絽が特に大 きくなる. 寸法精度重視の機械部品成形に当たつては， これを着肉層と見なすことはできないから，緻密に充填 された本来の着肉層を正確に測定するため，中間層を含 む金型内の着肉層に湘定子を押し込む方法を考案した。

実験装置をFig.2に示す，手順は,金型上部から着肉層 に対し鉛直方向に測定子を静かに㨉入し，測定子が止ま った状態で10sec間静置,次に測定子上部までの高さをハ イトゲージで測定した.ここで測定子に載せる重錘を適 当に選定すれば，中間層に影響されることなく正確な着 肉厚さを測定できる．重錘の大きさは以下の方法で決定 した.

石亳型を用いて加圧しない通常の鋳込みを行い,90min 後に泥淼を排出して着肉部分の水分分布を測定した結果 を最大,最小値を併記してFig.3に示す。試料数は50個で ある. 図中，鋳型界面か $55 \mathrm{~mm}$ までは水分量 $14 \%$ 以下で ばらつきが小さいが, 5 m吅を越えると水分量が多くばらつ きも大きい.このばらつきの大きい部分が中間層と見な される.そこで, 前述の方法による成形体高さの測定値 が5 mmとなるよう測定子の重鍾を調整したところ300gと なった.この場合, 着肉層と判定された部分の水分量の 標準偏差は，成形体高さの測定値に関係なく0.21mass\% と小さく，本押し込み法は実用度の高い測定法と考えら れる.

\section{4 成形体の乾燥・焼成}

成形体はまず室温で $8 \mathrm{hr}$, さらに $40^{\circ} \mathrm{C} て ゙ 8 \mathrm{hr}, 100^{\circ} \mathrm{C} て ゙$ $4 \mathrm{hr}$ 乾燥した. 次に, 大気炉により $120^{\circ} \mathrm{C} / \mathrm{hr}$ で昇温して $500^{\circ} \mathrm{C} て ゙ h r$ 脱脂を行い，その後 $200^{\circ} \mathrm{C} / \mathrm{hr}$ で舁温して800 'Cで1hr仮焼成，あるいは $1250^{\circ} \mathrm{C} て ゙ 1.5 \mathrm{hr}$ r焼成を行った. 
$\downarrow$ Compressed air (0.9MPa) $\quad \downarrow$

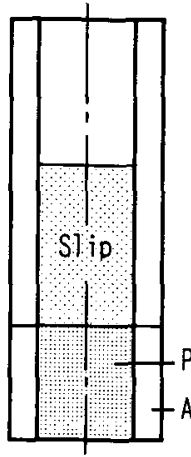

(1) With plaster

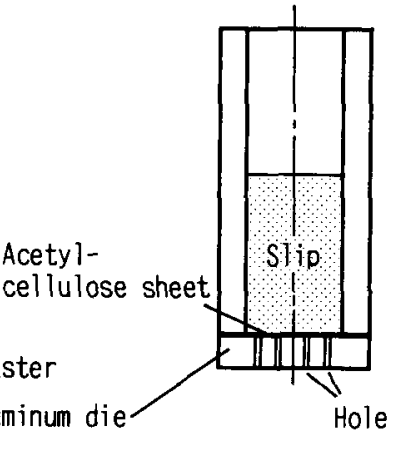

(2) With cellulose sheet

Fig.1 Molds.

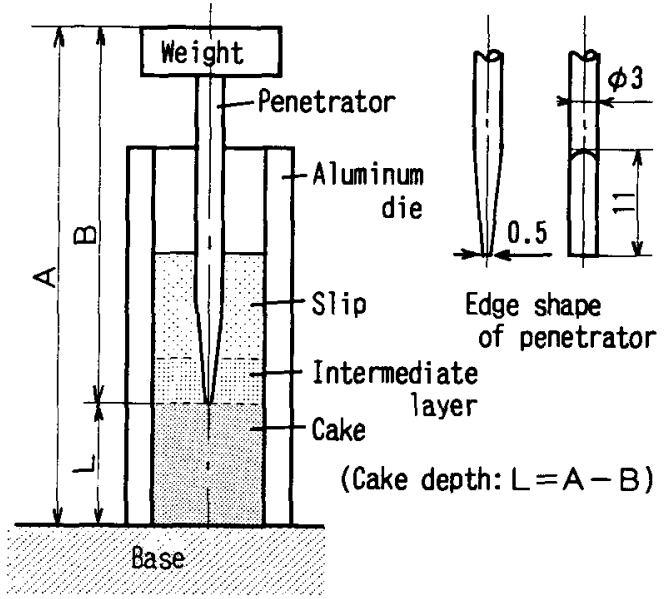

Fig.2 Apparatus for measurement of the cake depth formed from a slip.

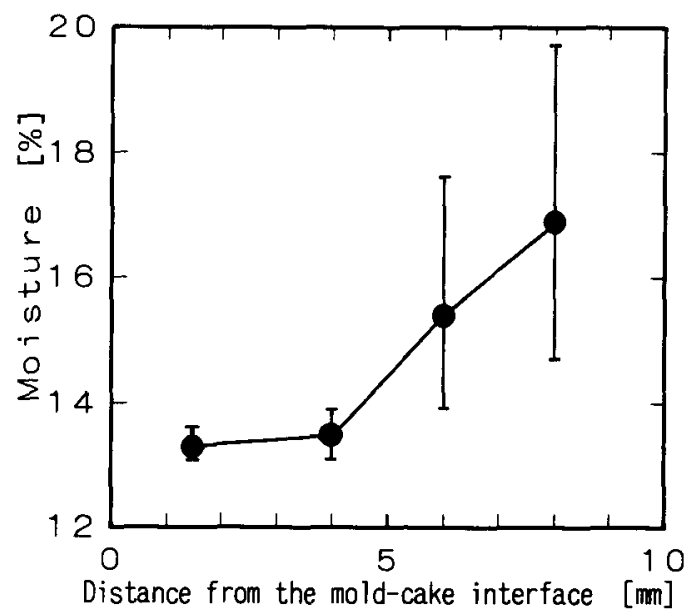

Fig. 3 Moisture distribution of cakes.
焼成後は炉中で $240^{\circ} \mathrm{C} / \mathrm{hr}$ で常温まで冷却した。

2.5 成形体及ひ焼成体の評価方法

成形体及ひ焼成体の評価は，ほほ直径 $10 \times$ 高さ12mmの 生成形体を作製して中央部で上下に切断し，それそれの 成形体水分量，粒子充填事, Ig.10ss $\left(800^{\circ} \mathrm{C}, 1 \mathrm{hr}\right.$ 灼熱減量), 焼成体かさ(相対)密度なとを測定して行った.また，焼成 体破面及ひ鏡面仕上け熱腐食面をSEMによって観察した。 なお,成形体粒子充填率は $800^{\circ} \mathrm{C}$ 仮焼成体を用いて水中 重量法により測定した。仮焼成体を用いたのは乾燥した だけの成形体では水中測定が困難なためである．また， 焼成体かさ密度も水中重量法により測定した。

\section{3 結果及び考察}

\section{1 着肉速度}

泥漿鋳込み成形における着肉厚さと着肉時間との関係 は, D.S.Adcock ら ${ }^{6)}$ 及び正笠7)等によって, 着因厚さの 2乗と時間が比例関係となることが示されている。すな わち,

$$
\begin{aligned}
\mathrm{L}^{2} \propto \mathrm{t} \\
\therefore \mathrm{K}=\mathrm{L}^{2} / \mathrm{t}
\end{aligned}
$$

ただし， $\mathrm{K}$ : 着肉速度定数 $\left(\mathrm{mm}^{2} / \mathrm{min}\right)$

$\mathrm{L}$ ：着肉厚さ $(\mathrm{mm})$

$\mathrm{t}:$ 時間(min)

石膏型及びセルロース・シートを用いて着肉速度を 測定した結果を，着肉速度定数 Kの計算結果も含めて Fig.4に示す.

石高型を使用して無加圧で鋳込んだ場合，Kが0.08 $\mathrm{mm}^{2}$ ／minと小さく，成形に長時間を要する.しかも，実際に 長時間連続して成形を続けると泥㯟は 2 次凝集するので，

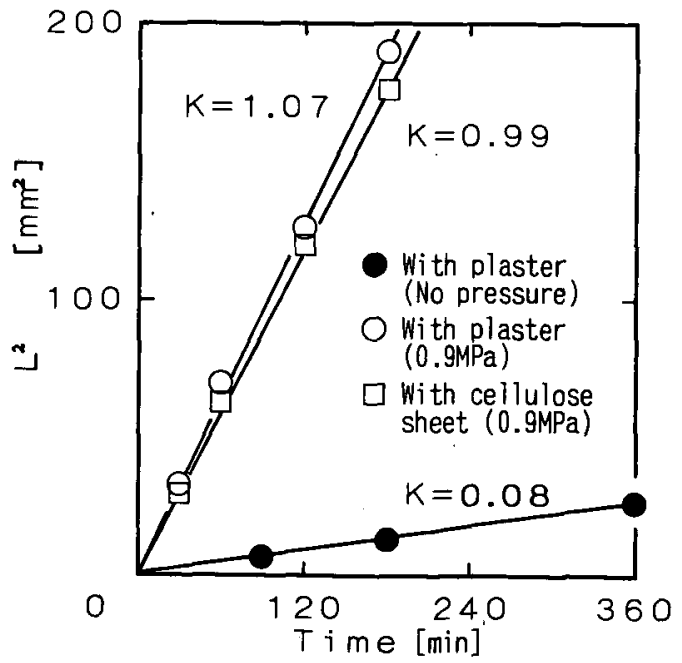

Fig.4 Relationship between $L^{2}$ and time. 
着肉が進行せず厚肉の成形体はできない. すなわち,こ の程度のK值では実用に適さないと考えられる．この様 に従来 ${ }^{8)}$ より低い值となったのは, 泥漿の粉体粒子が微 細化すると Kが小さくなる ${ }^{9}$ ことの他に, 従来の泥漿を 排出する方法による着肉厚さ測定法では着肉後に上澄み 泥漿を流し去るだけなので, 中間層を着肉層の一部とみ なしてKを過大に測定していた可能性がある. 不完全着 肉の中間層は, 成形体の粒子充填率が低く乾燥焼成時の 寸法変化率が大きいので, 寸法精度が重視されるファイ ンセラミックスの成形では従来のように着肉層として报 うべきではないと考えられる.

一方加圧成形は, 石高型の場合もセルロース・シート の場合も,共に $\mathrm{K} か ゙ 1.0 \mathrm{~mm}^{2} / \mathrm{min}$ 前後であった.このよう に石膏型を使用しても加圧することによってKを大きく することができる．またセルロース・シートと石高型の 值が同等なことから,これらはよく似た機構で着肉して いるのであろう4) .

\section{2 成形体の特性}

水分量, 粒子充填率, I g. 1 oss をTable 3 に示す. 水分量は石高型及びセルロース・シートのいずれを使用 しても, 13.3〜13.6\%でほぼ同様に低く, 上下方向の勾 配も小さい.

粒子充填率も石膏型及びセルロース・シート使用の両 場合に, 62.8〜63.0\%でほぼそろっており, 全てセラミ ックス成形体の理想的な粒子充填率である $60 \%$ を越えて いる.

I g. 1 ossでは,石衰型使用とセルロース・シート使用 に多少の違いが認められた.セルロース・シートでは成 形体水分量と同様に成形体上部で值が大きいのに対し, 石旁型では成形体下部の方が値が大きい.これは石膏型 表面から有機物を含んだ不純物が浸透したことを示唆し ている.

以上,石高型下部の I g. 1 ossを除いて全体的に均一で 良好な成形体が得られた. もちろんこれには, 従来の報 告と異なって不完全着肉部分(中間層)を除き, 本来の着 肉層のみで評価したことも寄与しているはずである.

\section{3 焼成体の特性}

$1250^{\circ} \mathrm{C}-1.5 \mathrm{hr}$ 焼成体の外観を検討したところ，石高型 を使用した場合, 成形体底部に焼成が他に比べ不完全な 部分が認められた. 焼成体を切断してガラス板上に置き, 光を透過して撮影した写真をPhoto.1に示す. セルロー ス・シート使用の場合は全体に半透光性であったが, 石 膏の場合に下部の型界面付近が白濁していた.この部分 の破面のS E M写真を $800^{\circ} \mathrm{C}$ 仮焼成体の破面と比較して
Photo.2に示す.アルミナ粒子の焼成が全く進行せず全体 に粒界破壊であり, $800^{\circ} \mathrm{C}$ 仮焼成体の破面に類似した状態 であった.この白濁部は, 無加圧の場合,成形時間 $4 \mathrm{hr}$ で の $3 \mathrm{~mm}$ まで徐々に成長しその後は変化がなく, 加圧の場 合, 成形時間 $1 \mathrm{hr}$ で $1.5 \mathrm{~mm}$ まで成長しその後多少薄くなる 傾向であった. 加圧した場合は泥漿から型方向への水の 流れが速く, 污染物質の拡散が防がれるのであろう.

この白濁部のみを切り取ってかさ(相対)密度を測定し た結果をFig. 5 に示す. 石高型を使用した場合, 上部では 相対密度が98.6\%以上であるが, 白濁部 (下部の界面か

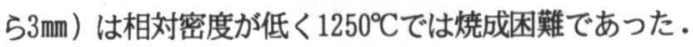
一方, セルロース・シートを使用した場合, 成形体上部, 下部が共に相対密度 $99 \%$ 以上になり, 均質な焼成体が得 られた.

Table 3 Properties of compacts. (\%)

(Pressure: 0.9MPa)

\begin{tabular}{|c|c|c|c|}
\hline & & Plaster & Cellulose \\
\hline \multirow{2}{*}{$\begin{array}{l}\text { Moisture of } \\
\text { green compact }\end{array}$} & Top & 13.5 & 13.6 \\
\hline & Bottom & 13.3 & 13.5 \\
\hline \multirow{2}{*}{$\begin{array}{l}\text { Relative } \\
\text { green density }\end{array}$} & Top & 62.8 & 62.9 \\
\hline & Bottom & 63.0 & 63.0 \\
\hline \multirow{2}{*}{ Ignition loss } & Top & 0.86 & 0.86 \\
\hline & Bottom & 0.92 & 0.76 \\
\hline
\end{tabular}

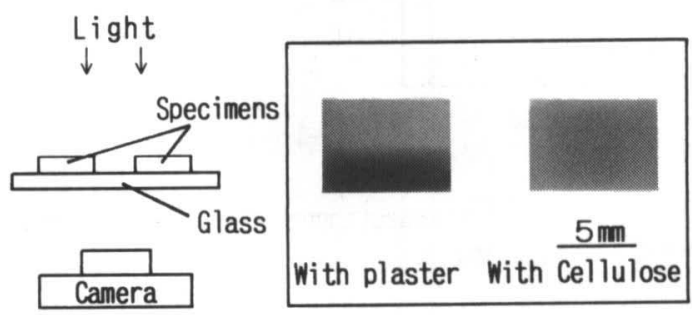

Photo.1 Transmission photograph of compacts sintered at $1250^{\circ} \mathrm{C}$ for $1.5 \mathrm{hr}$.

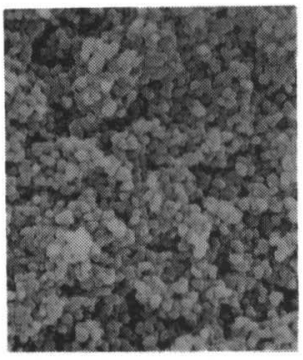

$800^{\circ} \mathrm{C}$

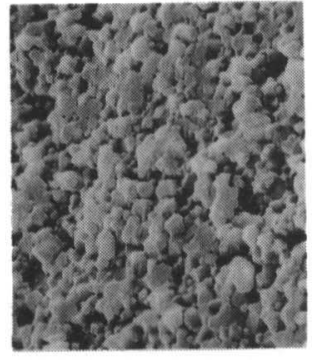

$1 \mu \mathrm{m}$
Photo.2 Scanning electron micrographs of fracture surfaces of a compact semi-sintered at $800^{\circ} \mathrm{C}$ for $1.0 \mathrm{hr}$, and a compact sintered at $1250^{\circ} \mathrm{C}$ for 1.5 $\mathrm{hr}$ showing an area near cake-plaster interface. 
石高型の場合に型界面部で焼成が進行しないのは, 水 田ら 3)が示しているように石膏型からのCaやSの污染に よるものと推測され，石高型による成形では高品質のア ルミナ焼成体を得ることが困難と考えられる．ただ, 型 界面から数mm以上内部では高い焼成密度が得られており， 成形後に表面を削除できる場合には石膏型でも問題ない であろう。

他方, セルロース・シートを使用した場合の $1250^{\circ} \mathrm{C}$ $1.5 \mathrm{hr}$ 焼成体について破面及び鏡面仕上げ熱腐食面を観 察したS E M写真はPhoto.3のようであった. 破壊は主 に粒内を通って進展しており, 熱腐食面でもボイドが観 察されず粒径がそろって全体に均一かつ緻密な組織が観 察された。熱腐食写真の切片長から算出した平均粒径は 約 $0.9 \mu \mathrm{m} て ゙$, 高強度が予想できる. 実際, この焼成体を 用いて4点曲げ強さ試験（JIS R1061）を行った結果は $724.2 \mathrm{MPa}$ （標準偏差83.3MPa）であり，ばらつきがやや 大きいが, ほぼ多孔樹脂型の場合 ${ }^{3)}$ と同等の高強度であ った.

従って, 多孔樹脂型に代えて使い捨てのセルロース・ シートを用いる本実験の方法では, 反復使用時の樹脂型

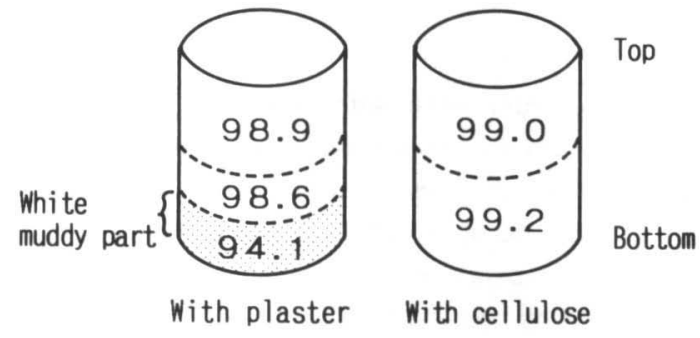

Fig. 5 Relative density in $1250^{\circ} \mathrm{C}-1.5 \mathrm{hr}$ sintered compacts. (\%)

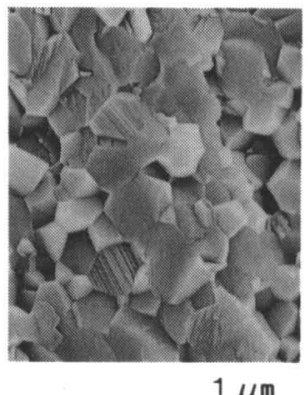

Fracture surface

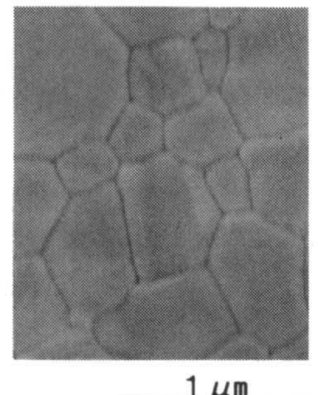

Pol ished-andthermal-etched surface
Photo.3 Scanning electron micrographs of fracture surface and polished-and-thermal-etched surface of compacts sintered at $1250^{\circ} \mathrm{C}$ for $1.5 \mathrm{hr}$.
の目詰まり問題を回避し，しかも樹脂型と同様に型から の污染も回避できることが長所である.

\section{4 結 論}

平均粒径 $0.22 \mu \mathrm{m}$ の高純度アルミナ超微粉の泥漿を用 いて加圧鋳込み成形法 $(0.9 \mathrm{MPa})$ について検討し, 次のよ うな結果を得た。

1 . 着肉部に直接測定子を押し込む測定法によれば, 従 来の泥浆を排出する方法に比べ実際的な着肉速度が測定 できる.

2.1．の方法によると, 本実験で使用したアルミナ超 微粉の着肉速度は, 加圧した場合, 石膏型及ひセセルロス・シートのいずれを使用しても定数 $\mathrm{K} \fallingdotseq 1.0 \mathrm{~mm}^{2} / \min て ゙$ あってかなり速いが, 石膏型を使用して加圧しない場合

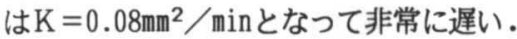

3. 石亮型を使用した場合, 加圧の有無に関係なく型表 面から不純物の污染があり焼成が阻害される. 污染層の 最大厚さは, 無加圧の場合成形時間約 $4 \mathrm{hr} て ゙$ 約 $3 \mathrm{~mm}$, 加圧 の場合成形時間1hrで約 $1.5 \mathrm{~mm}$ である.

4. セルロース・シートを使用して加圧成形した場合, $1250^{\circ} \mathrm{C}$ の低温焼成で, 微細で繶密かつ高強度の焼成体 (平均粒径 $0.9 \mu \mathrm{m}$, 相対密度 $99 \%$ 以上, 4 点曲け強度 700 MPa以上)を得ることができ, 多孔樹脂型と同程度の結果 であった.

\section{文 献}

1)高橋実,鈴木傑: ケミカルエンジニアリング,(1987)281 。 2) 水田博之,芝崎靖雄, 酒井清介, 片桐 誠,藤本久和: 粉体 および粉末治金, 35(1988）619.

3)水田博之,芝崎靖雄:金属, 59(1989) 6,14

4) 星幸二,深谷英世,伊藤政巳: 愛知県常滑案業技術セン 夕一報告, $17(1990) 35$.

5) 田島俊造,隅田雅之,黒木英憲: 粉体および粉末治金, 39 (1992) 39.

6) D.S.Adcock and I.C.McDowall: J.Am.Ceram.Soc., 40 (1957) 355.

7) 正笠俊司：日本機械学会第68期全国大会講演会講演論 文集 Vol.A,218(1990).

8)内村勝次: セラミックスの成形法の新しい概念とノウ ハウについての徹底研究, 日本セラミックス協会陶磁器 部会 (1991.7.12開催)資料, 42.

9) 滝本幹夫: セラミックスの成形法の新しい概念とノウ ハウについての徹底研究, 日本セラミックス協会陶磁器 部会 (1991.7.12開催)資料, 26. 